\title{
The Noncanonical Heat Shock Protein PvNod22 Is Essential for Infection Thread Progression During Rhizobial Endosymbiosis in Common Bean
}

\author{
Jonathan Rodríguez-López, Alejandrina Hernández López, Georgina Estrada-Navarrete, \\ Federico Sánchez, and Claudia Díaz-Camino ${ }^{\dagger}$
}

Departamento de Biología Molecular de Plantas, Instituto de Biotecnología, Universidad Nacional Autónoma de México, Avenida Universidad 2001, Colonia Chamilpa, Cuernavaca, Morelos 62210, Mexico

Accepted 15 March 2019.

\begin{abstract}
In the establishment of plant-rhizobial symbiosis, the plant hosts express nodulin proteins during root nodule organogenesis. A limited number of nodulins have been characterized, and these perform essential functions in root nodule development and metabolism. Most nodulins are expressed in the nodule and at lower levels in other plant tissues. Previously, we isolated Nodulin 22 (PvNod22) from a common bean (Phaseolus vulgaris L.) cDNA library derived from Rhizobium-infected roots. $P v$ Nod22 is a noncanonical, endoplasmic reticulum (ER)-localized, small heat shock protein that confers protection against oxidative stress when overexpressed in Escherichia coli. Virus-induced gene silencing of PvNod22 resulted in necrotic lesions in the aerial organs of $P$. vulgaris plants cultivated under optimal conditions, activation of the ER-unfolded protein response (UPR), and, finally, plant death. Here, we examined the expression of $P v N o d 22$ in common bean plants during the establishment of rhizobial endosymbiosis and its relationship with two cellular processes associated with plant immunity, the UPR and autophagy. In the RNA interference lines, numerous infection threads stopped their progression before reaching the cortex cell layer of the root, and nodules contained fewer nitrogen-fixing bacteroids. Collectively, our results suggest that $P v$ Nod22 has a nonredundant function during legumerhizobia symbiosis associated with infection thread elongation, likely by sustaining protein homeostasis in the ER.
\end{abstract}

Keywords: $\alpha$-crystallins, autophagy, endoplasmic reticulum, legumerhizobia symbiosis, molecular chaperones, Phaseolus vulgaris (common bean), rhizobium-legume symbiosis, small heat-shock proteins, unfolded protein response

In loving memory of Federico Sánchez.

${ }^{\dagger}$ Corresponding author: C. Díaz-Camino; claudia@ibt.unam.mx

Funding: J. I. Rodríguez-López was supported by a Ph.D. scholarship (207200) from Consejo Nacional de Ciencia y Tecnología (CONACYT)México. This research was partially supported by diverse research grants from CONACYT-México to F. Sánchez and from the Dirección General Asuntos del Personal Académico, Universidad Nacional Autónoma de México (PAPIIT numbers IN206815 and IN201418) to C. Díaz-Camino.

*The $\boldsymbol{e}$-Xtra logo stands for "electronic extra" and indicates that one supplementary table and two supplementary figures are published online.

The author(s) declare no conflict of interest.

๑) 2019 The American Phytopathological Society
Many leguminous plants engage in symbiosis with facultative nitrogen-fixing soil bacteria (collectively known as rhizobia). This biological interaction is initiated by nitrogen starvation of the host plant, and the exudation of specific flavonoids into the rhizosphere to attract compatible rhizobia. In response to the flavonoids, the attracted bacteria produce and secrete nodulation (Nod) factors, which activate many of the early events in root hair infection, including root hair curling and the reorientation of root hair growth, which results in the formation of an intracellular tubular structure called the infection thread (IT). Within the IT, rhizobia enter the root hair cell and eventually ramify into the root cortex. Concurrently, the cortical cells underneath the root hair reactivate the cell cycle to form the nodule primordium, where the invading rhizobia are released from the ITs and internalized into the host cytosol to form intracellular organelles called symbiosomes. There, rhizobia differentiate into the distinct bacteroid (BT) form that can fix nitrogen (Crespi and Frugier 2008; Mortier et al. 2012).

During nodule organogenesis, a set of plant-specific genes encoding nodulin proteins is induced (Stougaard 2001). Although only a few nodulins have been fully characterized, it has been proposed that nodulins have evolved to fit the regulatory or physiological constraints of symbiotic nitrogen fixation. As a consequence, most nodulins tend to be expressed at low levels in other plant tissues compared with the nodule. Similar to other nodulins, Nodulin 22 (PvNod22) transcripts are barely detected in common bean (Phaseolus vulgaris L.) plants during optimal growth conditions (Rodriguez-López et al. 2014). However, $P v \operatorname{Nod} 22$ expression is highly induced during root nodule development and in roots with active nodules (Mohammad et al. 2004). In addition, $P v \operatorname{Nod} 22$ expression may be induced by heat and reactive oxygen species (ROS) (Rodriguez-López et al. 2014).

The predicted $P v \operatorname{Nod} 22$ protein contains a highly hydrophobic $\mathrm{N}$ terminus and a $\mathrm{C}$-terminal extension with high identity to the $\alpha$-crystallin domains found in $\alpha$-crystallin lens chaperone proteins and other small heat-shock proteins (sHsps) (Mohammad et al. 2004). Indeed, $P v \operatorname{Nod} 22$ facilitated the refolding of a model substrate in vitro, suggesting that it acts as a molecular chaperone in the cell. $P v \operatorname{Nod} 22$ resides in the endoplasmic reticulum (ER) (Rodriguez-López et al. 2014).

The ER is the main cellular compartment for biosynthesis of most transmembrane and secreted proteins, and a wide array of chaperones are actively involved in the synthesis, folding, modification, packing, and transport of these secreted proteins. However, diverse environmental and physiological stress 
conditions perturb these processes, causing accumulation of damaged or misfolded proteins in the ER lumen. The ER responds to this condition by activating the unfolded protein response (UPR) through a signal transduction cascade that orchestrates ER protein homeostasis by upregulating protein folding and degradation pathways (Angelos et al. 2017; Yang et al. 2016). There are two branches to this pathway in Arabidopsis thaliana: a branch modulated by the two paralogs of mammalian inositol-requiring enzyme 1 (IRE1a and IRE1b), and its mRNA splicing target membrane-associated basic leucine zipper domain 60 (bZip60), and a second branch mediated by the proteolytic processing of bZip28/bZip17 (Chen and Brandizzi 2012; Mishiba et al. 2013; Nagashima et al. 2011; Sun et al. 2013). Additionally, the plant B-cell lymphoma2 (Bcl-2)-associated athanogene 7 (BAG7) protein mediates the heat-induced UPR pathway in plants (Q. Li et al. 2017). A secondary transcriptional regulatory cascade of the UPR involving the activation of plant-specific NAC transcription factors (Chi et al. 2017; Shao et al. 2015; Yang et al. 2014) has also been reported but not fully characterized. Once triggered, these transcription factors modulate the expression of the downstream UPR target genes (Deng et al. 2011; Q. Li et al. 2017; Moreno et al. 2012; Nagashima et al. 2014), including the gene encoding binding immunoglobulin protein 3 (BiP3), the main biomarker of UPR activation (Iwata and Koizumi 2012; Liu and Howell 2010).

Additionally, autophagy, a major pathway for the delivery of proteins and cellular components to the vacuole for degradation, is also activated by IRE1 under UPR (Liu et al. 2012; Yang et al. 2016). The turnover of the ER membrane and its contents mediated by autophagy contributes to ER stress recovery. Interestingly, autophagy has a central role in response to abiotic stress and in modulating plant resistance to diverse microbes, including rhizobia (Bao and Howell 2017; Estrada-Navarrete

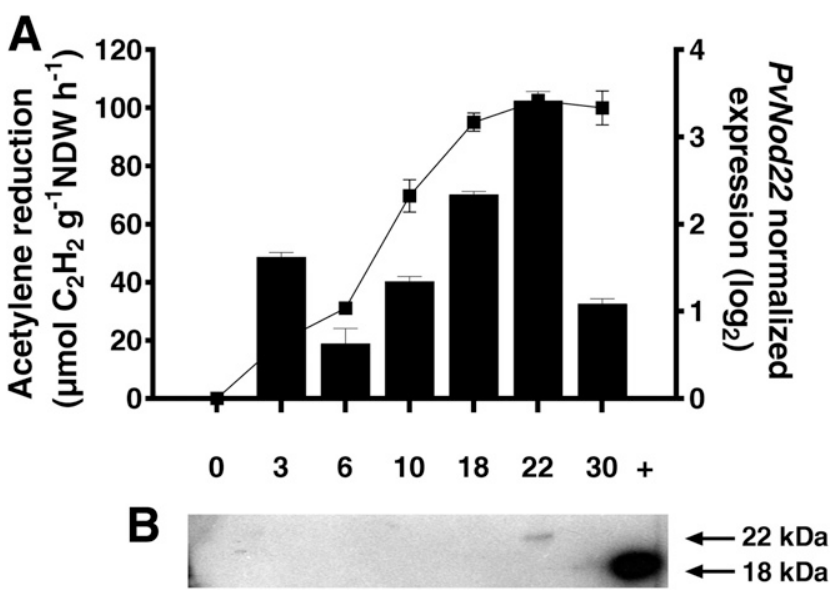

Fig. 1. PvNod 22 expression is induced during nodulation. A, Accumulation of $P v N o d 22$ transcripts in common bean roots during nodulation (days postinfection). Nine roots were pooled in each biological replicate, and data show mean values from three independent experiments (black columns) $(n=3)$. Reverse-transcription quantitative PCR data were normalized against $P v E F 1-\alpha$ expression. The fold change in gene expression was obtained by comparing the expression of the PvNod 22 gene in inoculated roots with its expression in uninoculated roots. Data are the mean values of PvNod22 transcript accumulation \pm standard deviation, and the statistical significance was determined with an unpaired two-tailed Student's $t$ test, $P<0.001$. The nitrogenase activity of nodules from nine plant roots was determined using an acetylene reduction assay (black squares in line) $(n=3)$. B, Immunoblot analysis of samples equivalent to those in A using a purified antibody against $P v \operatorname{Nod} 22$. Column + shows the identification of the positive control (recombinant $P v \operatorname{Nod} 22$ without the signal peptide, $20 \mathrm{kDa}$ ). $P v \operatorname{Nod} 22$ is only detected at 22 days postinfection $(22 \mathrm{kDa})$. et al. 2016; Hampel et al. 2016; Hof et al. 2014; Kabbage et al. 2013).

When the UPR becomes insufficient under conditions of chronic stress and increasing cell damage, the UPR commits the cell to programmed cell death (PCD). In mammals and yeast, the core components of the PCD machinery are the UPR, autophagy, and $\mathrm{Ca}^{2+}$ signaling between the ER and mitochondria. These components have also been identified in plants, thus linking the UPR to PCD and innate immunity (Ma and Berkowitz 2007; Martinon and Glimcher 2011; Stael et al. 2012).

In this work, we explore the functional role of $P v \operatorname{Nod} 22$ during the symbiotic interaction of common bean ( $P$. vulgaris) with Rhizobium tropici. RNA interference-mediated downregulation of $P v N o d 22$ diminishes IT progression and decreases the BT number in nodule cells, thus affecting nodule nitrogenfixing ability. At the molecular level, silencing of PvNod22 exacerbates ER stress.

\section{RESULTS}

PvNod22 transcripts progressively accumulate during nodule ontogeny.

We determined the expression of PvNod22 during the symbiosis of bean plants and $R$. tropici by reverse-transcription quantitative PCR (RT-qPCR) (Fig. 1A). In these experiments, nine uninoculated or inoculated roots of common bean plants were pooled for each biological replicate. Experiments were repeated three times. At 3 days postinoculation (dpi), expression of PvNod22 was transiently activated (3.5-fold change compared with uninoculated roots), to reach its maximum expression level at $22 \mathrm{dpi}$ (10.7-fold change). These data agree with previous reports from our laboratory, where $P v N o d 22$ transcripts were identified in bean roots inoculated with $R$. etli CE3 at 7, 17, and 21 dpi (Mohammad et al. 2004). However, at the onset of nodule senescence (approximately $30 \mathrm{dpi}$ ), PvNod22 transcript levels begin to return to basal levels (2.1fold compared with uninoculated roots). Nodule senescence is distinguished by a decrease in nitrogen-fixation levels and an increase in ROS. During this developmental stage, antioxidant defenses diminish, leghemoglobin is oxidized to characteristic green pigments, and autolytic processes are enhanced (Evans et al. 1999; Matamoros et al. 1999, 2003). As a consequence, root nodules turn from pink to pale green or even to gray.

Interestingly, $P v N o d 22$ expression in symbiotic nodules and their maximum nitrogen-fixing activity both peaked at $22 \mathrm{dpi}$ $\left(\mathrm{C}_{2} \mathrm{H}_{2}\right.$ at $103.0 \pm 1.10 \% \mu \mathrm{mol} \mathrm{g}^{-1}$ nodule $\left.\mathrm{DW} \mathrm{h}{ }^{-1}\right)($ Fig. $1 \mathrm{~A})$, during which high levels of ROS are produced (Moran et al. 2000). Using specific antibodies against an epitope of $P v \operatorname{Nod} 22$, we could detect the presence of unprocessed $P v \operatorname{Nod} 22$ (with signal peptide) in nodule protein extracts at 22 dpi (Fig. 1B), just where the highest $P v N o d 22$ mRNA accumulation is reached (Fig. 1A). In vitro, recombinant $P v \operatorname{Nod} 22$ (which does not have a signal peptide) forms high molecular weight oligomers that are not recognized by the $P v \operatorname{Nod} 22$ antibody; thus, it is possible that, in nodule protein extracts, most processed $P v \operatorname{Nod} 22$ is organized into homo- or hetero-oligomers that are not detected by the $P v \operatorname{Nod} 22$ antibody.

Given that $P v$ Nod22 is an ER-resident protein linked to UPR (Rodriguez-López et al. 2014), we analyzed the expression of a set of genes related to the UPR and to autophagy throughout symbiosis. Compared with control (uninoculated) roots, the expression of UPR-related genes is induced during nodulation (Fig. 2A). Interestingly, the accumulation of the PvNod22 transcript during nodulation resembles the expression levels of IRE1a (Fig. 1A compared with Fig. 2A).

In plants, the primary target of IRE is the bZip60 mRNA. Under normal growth conditions, bZip60 mRNA is transcribed 
and translated, and encodes an ER membrane-anchored transcription factor; however, in response to stress, IRE splicing causes a frame shift in bZip60 that eliminates the transmembrane domain, yielding a form of bZip60 targeted to the nucleus (Deng et al. 2011). Once in the nucleus, bZip60 activates the expression of UPR genes via direct binding to the UPR element (Nagashima et al. 2011). In parallel, IRE1 activates autophagy, which delivers ER contents to the vacuole for degradation (Liu et al. 2012; Yang et al. 2016).

To confirm the activation of the UPR during nodulation, we quantified the expression levels of the spliced form of bZip60 mRNA (Supplementary Fig. S1). In this analysis, RT-PCR assays were performed using primers depicted in Supplementary Table S1. The bZip60 expression levels were normalized to the expression of the elongation factor (EF) gene $(P v E F 1-\alpha)$, and the fold change in bZip60 expression was calculated as the ratio of its expression in inoculated roots with its expression in uninoculated roots. Compared with the unspliced form of bZip60 (361 bp), accumulation of the spliced bZip60 (312 bp) mRNA gradually increases during nodulation, then diminishes at $30 \mathrm{dpi}$, when nodule senescence initiates. In addition, the expression of core autophagy genes (Fig. 2B) was induced after rhizobia infection and sustained throughout symbiosis, consistent with the idea that autophagy is involved in this process (Estrada-Navarrete et al. 2016; Gavrin et al. 2014). We used in silico computational analyses of promoters (Chow et al. 2016) to identify key regulators of the $P v N o d 22$ transcriptional response (Supplementary Fig. S2) and found multiple canonical sites for binding of bZip and NAC transcription factors (Bailey and O'Hare 2007; Sun et al. 2013). These factors form part of the transcriptional regulatory cascade of the UPR (Chen and Brandizzi 2012; Chi et al. 2017; Mishiba et al. 2013; Nagashima et al. 2011; Shao et al. 2015; Sun et al. 2013; Yang et al. 2014).

Collectively, our findings suggest PvNod22 might be part of the gene regulatory network that is upregulated by the UPR during symbiosis. Moreover, the expression of $P v N o d 22$ at the same time as the onset of nitrogen fixation, as well as its early accumulation after contact with rhizobia, suggest that $P v$ Nod22 may play important roles in the process of tissue and cell invasion by the symbiont, as well as in adapting nodule physiology for its specialized role in biological nitrogen fixation.

\section{$P v$ Nod22 is required during early stages of the bean- $R$. tropici symbiosis for IT progression.}

In tropical legumes such as common bean, rhizobia gain access to internal root cells through ITs. Rhizobia enter and divide within ITs, which subsequently traverse the root hair to reach the outer cortex, where the nodule primordium is being formed (Crespi and Frugier 2008; Mortier et al. 2012). To determine the functional role of $P v \operatorname{Nod} 22$ during rhizobia root invasion, we produced common bean plants with transgenic roots using Agrobacterium rhizogenes-mediated root transformation (Estrada-Navarrete et al. 2007) with one of two RNA interference (RNAi) constructs, targeting the nonconserved 5' (PvNod22-RNAi-1) or 3' (PvNod22-RNAi-2) untranslated region of $P v N o d 22$. PvNod22 silencing was confirmed by RTqPCR (Fig. 3A). In 10 independent transgenic hairy roots expressing $P v N o d 22-R N A i-1$ or $P v N o d 22-R N A i-2$, the efficiency of these constructs in mediating PvNod22 mRNA degradation was similar (Fig. 3A). Expression levels of PvNod22 transcript were reduced by approximately $70 \%$ when compared with the levels found in individual control transgenic roots. We did not observe any changes in root growth or general architecture when comparing uninoculated or inoculated A. rhizogenes untransformed-, empty vector-transformed, or $P v$ Nod22-RNAitransformed roots.

Negative control (pTdT-Sac-RNAi) or PvNod22-RNAi transgenic roots of composite bean plants were inoculated with equivalent $R$. tropici-green fluorescent protein (GFP) concentrations and examined under a confocal microscope at 7 and 15 dpi. Infection thread progression and ramification were traced based on GFP fluorescence. In these experiments, 50 independent transgenic hairy roots of each variant were analyzed. Representative images of these experiments at 7 dpi are shown in Figure 3. Negative control and PvNod22-RNAi-1 transgenic hairy roots show the typical root hair curling deformation associated with host recognition (Mortier et al. 2012) (Fig. 3C and F), suggesting that this process was not affected by the silencing of $P v N o d 22$. However, when we examined the roots
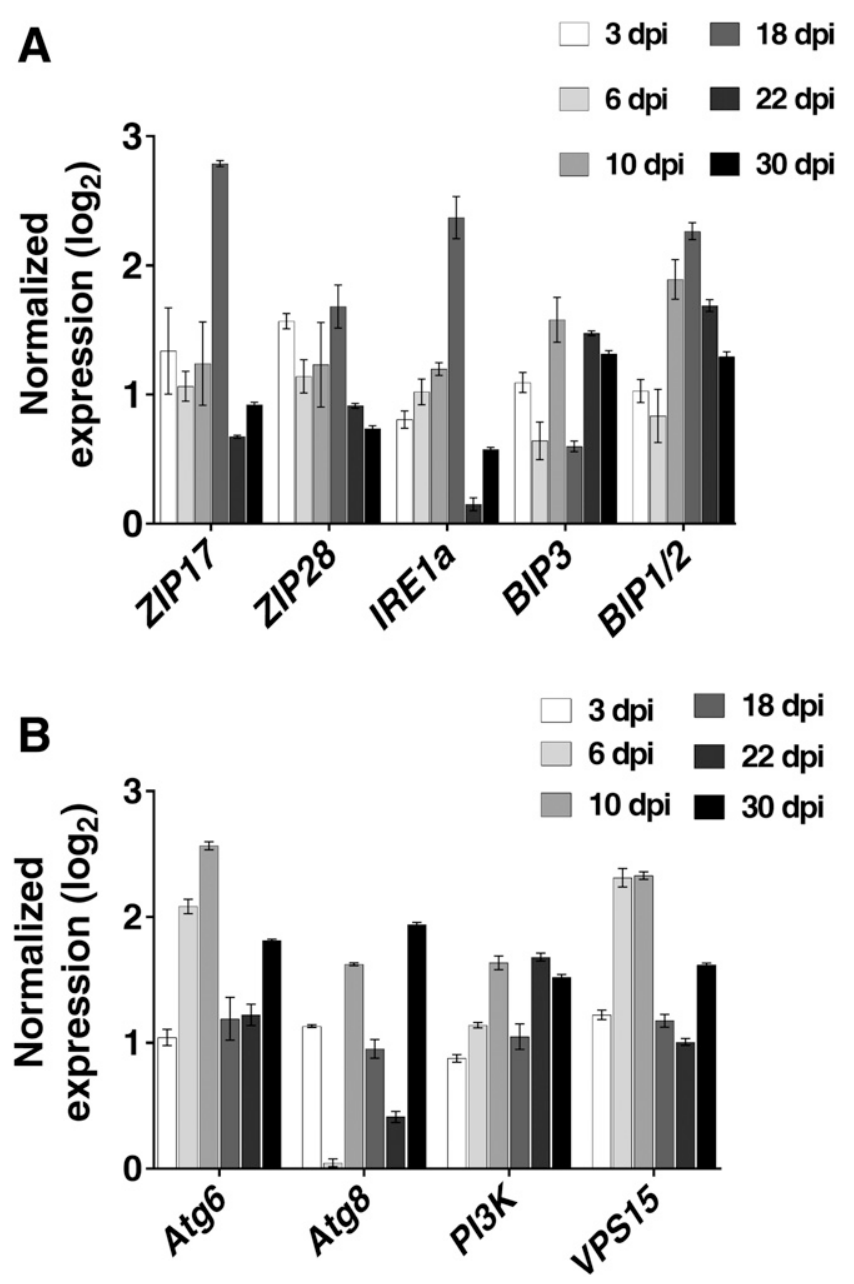

Fig. 2. Unfolded protein response (UPR) and autophagy salvage pathways are activated during common bean-rhizobia symbiosis. Two-day-old common bean seedlings were transferred to pots containing sterilized vermiculite, inoculated with $1 \mathrm{ml}$ of $10 \mathrm{mM} \mathrm{MgSO}_{4}$ or with $7 \times 10^{7} R$. tropici CIAT899 cells suspended in $1 \mathrm{ml}$ of $10 \mathrm{mM} \mathrm{MgSO}_{4}$. Plants were grown in a glasshouse with a controlled environment for several days. Accumulation of $\mathbf{A}$, UPR-related $\mathbf{B}$, or autophagy-related gene transcripts along nodule ontogeny as determined by reverse-transcription quantitative PCR from nine roots pooled per replicate $(n=3)$ are shown; dpi $=$ days postinfection. The fold change in gene expression was obtained by comparing the expression of the genes in uninoculated (negative control) versus inoculated roots. Data show mean values. Data were normalized to the expression of $P v E F 1-\alpha$. Data are the mean values of transcript accumulation \pm standard deviation, and the statistical significance was determined with an unpaired two-tailed Student's $t$ test, $P<0.001$. 
closely, we noticed that many of the ITs formed in PvNod22RNAi-1 or PvNod22-RNAi-2 transgenic roots were delayed in their progression to the nodule compared with control roots. In these ITs, their progression toward the first dividing cell layer beneath the infection site was detained at the base of the infected root hair (Fig. 3G compared with 3D). Microscopy observations at 15 dpi revealed that this phenotype was more prevalent in $P v N o d 22$-silenced bean roots than in control roots $(66.0 \pm 9.1$ in $P v N o d 22-R N A i-1$ and $63.0 \pm 3.0$ in PvNod22RNAi-2 roots, compared with $40.0 \pm 8.0$ in the control) (Fig. 3B). These data suggest that $P v N o d 22$ function could be related to IT progression in early symbiosis.
A

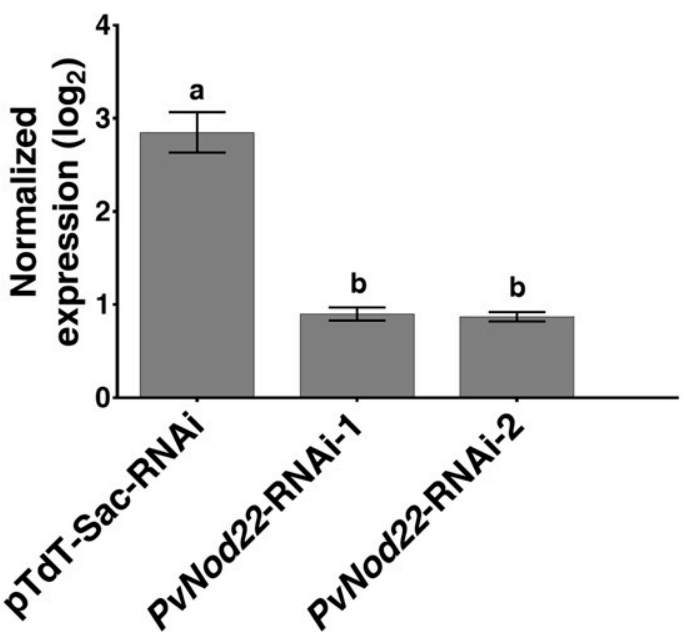

B

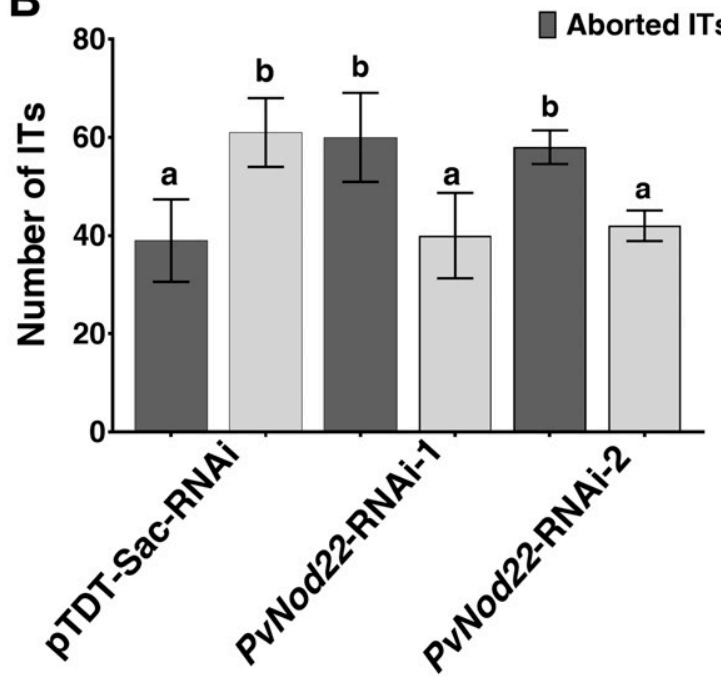

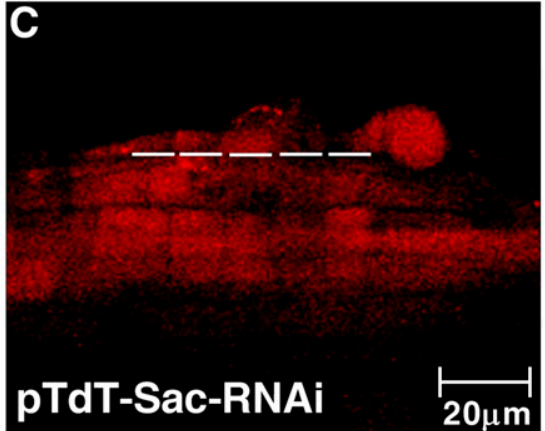
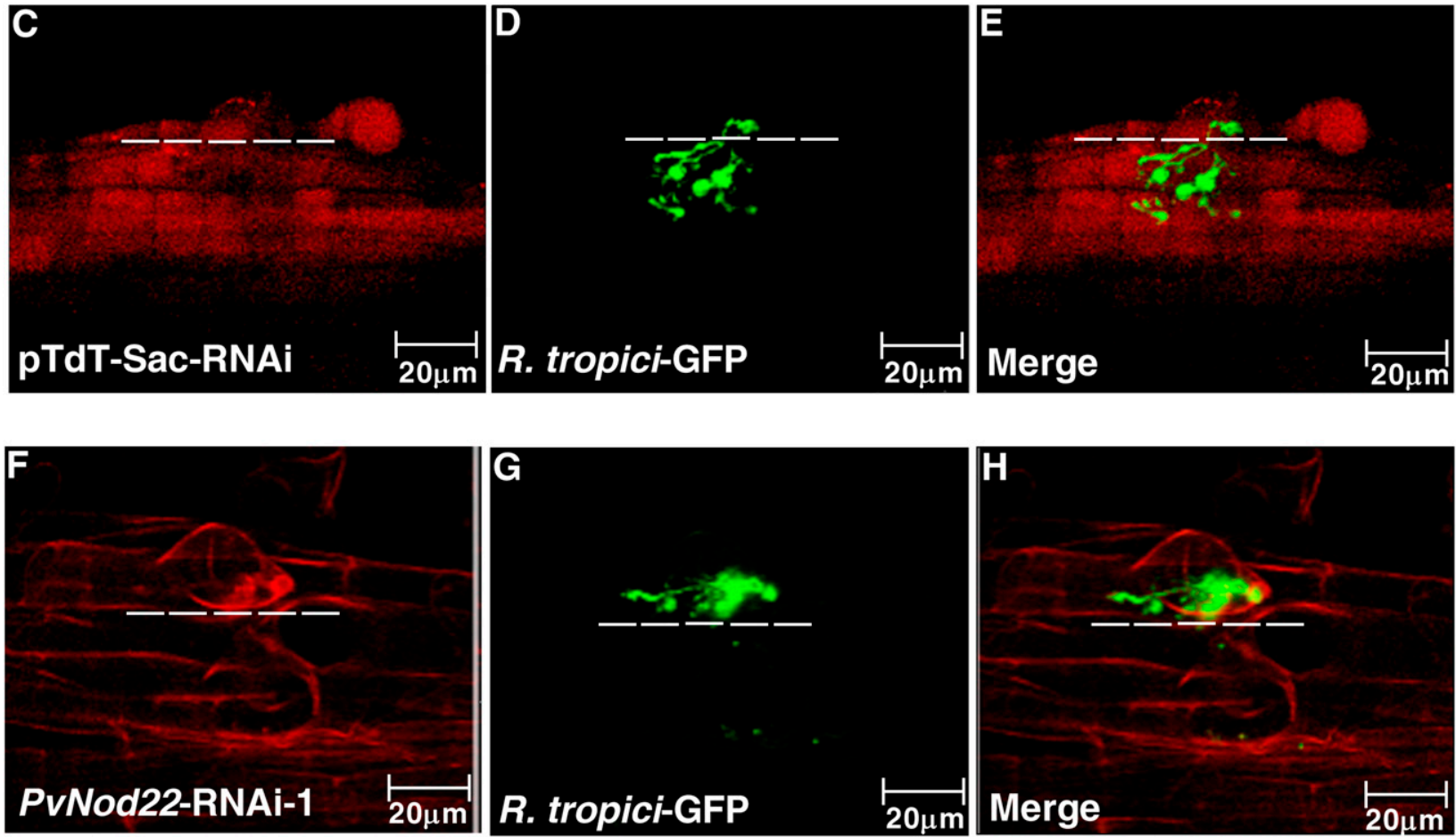

Fig. 3. Downregulation of $P v N o d 22$ increases the rate of infection thread (IT) abortion. A, PvNod 22 transcript levels in Rhizobium tropici CIAT899-inoculated pTdT-Sac-RNA interference (RNAi) (control) and PvNod22-RNAi-1- and PvNod22-RNAi-2-transformed hairy roots of composite bean plants $(n=9$ each) determined by reverse-transcription quantitative PCR. Data were normalized to the expression of $P v E F 1-\alpha$. Plotted data are the mean values of $P v N o d 22$ transcript accumulation \pm standard deviation. The statistical significance was determined using an unpaired two-tailed Student's $t$ test, $P<0.001$. B, Fifteen days after inoculation with $R$. tropici CIAT899 expressing green fluorescent protein (GFP), pTdT-Sac-RNAi (control), and PvNod22-RNAi-1- and PvNod22RNAi-2-infected roots were observed using a confocal microscope. ITs were quantified and classified as "in active progression" or "aborted", based on whether their progression toward the first dividing cell layer beneath the infection site was detained at the base of the infected root hair. The statistical significance was determined with an unpaired two-tailed Student's $t$ test, $P<0.001$. Hairy roots transformed with control or PvNod22-RNAi-1 were inoculated with $R$. tropici CIAT899-GFP. IT progression and ramification were traced by the fluorescence of GFP. Confocal images show C, root hair curling; D, IT progression; and E, merge in control transformed roots and $\mathbf{F}$, root hair curling; $\mathbf{G}$, IT progression; and $\mathbf{H}$, merge in PvNod22-RNAi-1 transgenic roots. White dashed lines indicate the border between the root epidermis and the adjacent cortical cell layer. Transgenic roots were analyzed at 7 days after infection. Bars $=20 \mu \mathrm{m}$. 
Silencing of $P v$ Nod22 decreases the infection level of nitrogen-fixing cells within the nodule.

Despite the high number of ITs that were arrested in their progression to nodule cells in rhizobia-inoculated PvNod22silenced roots, the number of nodules in PvNod22 knockdown roots of composite plants was approximately two times greater than in the control (Fig. 4A). However, the majority of these nodules were smaller in size compared with control nodules, and were not pink, a common feature observed in young or defective nitrogen-fixing nodules. Indeed, the nitrogen fixation rate of PvNod22-RNAi-1 and PvNod22-RNAi-2 22 dpi root nodules was 2.3 to 2.5 times lower $(42 \pm 9.3 \%$ and $38.6 \pm 2.0 \%$ $\mu \mathrm{mol}^{-1}$ of ethylene $\mathrm{h}^{-1} \mathrm{~g}^{-1}$ nodule dry weight, respectively) when compared with control root nodules $\left(100 \pm 7.0 \% \mu \mathrm{mol}^{-1}\right.$ of ethylene $\mathrm{h}^{-1} \mathrm{~g}^{-1}$ nodule dry weight).

In common bean nodules, the cortical tissue surrounds the central tissue, which consists of BT-containing cells and interstitial cells. Bacteroidal tissue is arranged in concentric zones, with the oldest cells at the center of the nodule. Toluidine blue-stained transverse sections of $R$. tropici-inoculated negative control or $P v N o d 22-$ RNAi nodules at 22 dpi display similar structural organization. However, whereas most cells in the central tissue of control nodules were infected with rhizobia (Fig. 4B and D), just 40 to $50 \%$ were infected in PvNod22RNAi-1 or PvNod22-RNAi-2 nodules, respectively (Fig. 4B, E, and F). Because BTs within bean nodules maintain their ability to reproduce on agar plates, we determined the number of viable BTs within control or PvNod22 loss-of-function 22-dpi nodules by CFU assays (Fig. 4C). These assays showed that the number of rhizobia declined by approximately $60 \%$ in 22-dpi PvNod22-RNAi-1 or PvNod22-RNAi-2 (22.6 \pm 4.1 and $26.5 \pm$ 4.1 CFU, respectively) nodules compared with the control $(57.3 \pm 4.2)$.

In infected cells of determinate nodules, rhizobia divide within the plant membrane and form symbiosomes with multiple BTs (multi-BTs) able to fix nitrogen (Brewin 2004). Ultrastructural analysis of control and PvNod22-RNAi nodules (Fig. 4D to F, insets) revealed the presence of multi-BTs, which were normal in size, and in poly-3-hydroxybutyrate content, surrounded by the symbiosome membrane (SB). In common bean nodules, the presence of multi-BTs per SB is found in mature, active nitrogen-fixing nodules (Cermola et al. 2000). We did not observe empty or abnormal BTs in any case, suggesting that the silencing of $P v \operatorname{Nod} 22$ does not compromise BT viability.

\section{Silencing of PvNod22 modifies the expression of UPR and autophagy-related genes.}

Because $P v$ Nod 22 is an ER-resident chaperone highly expressed in common bean root nodules during active nitrogen fixation (Mohammad et al. 2004; Rodriguez-López et al. 2014) (this work), and considering that the UPR and autophagy are
A
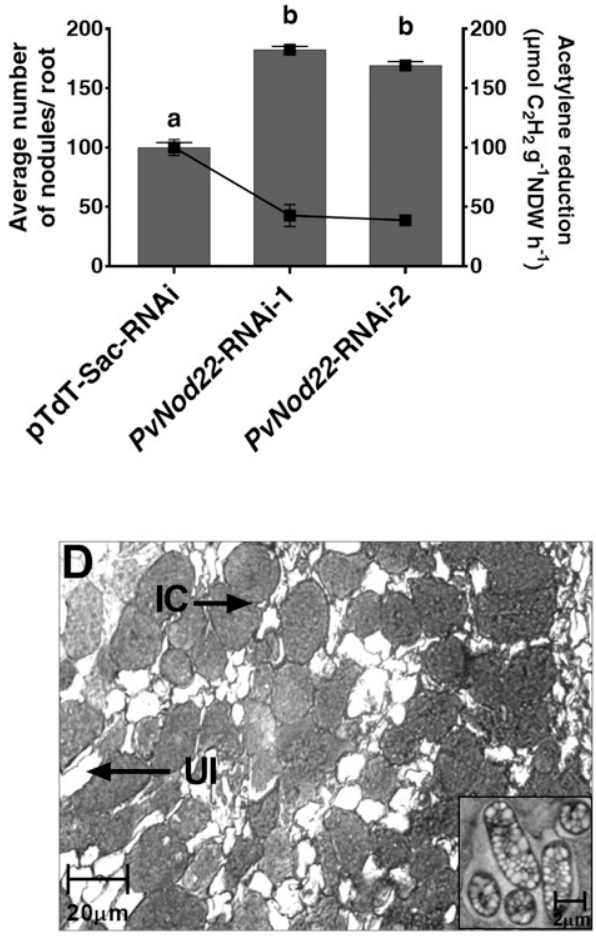

B
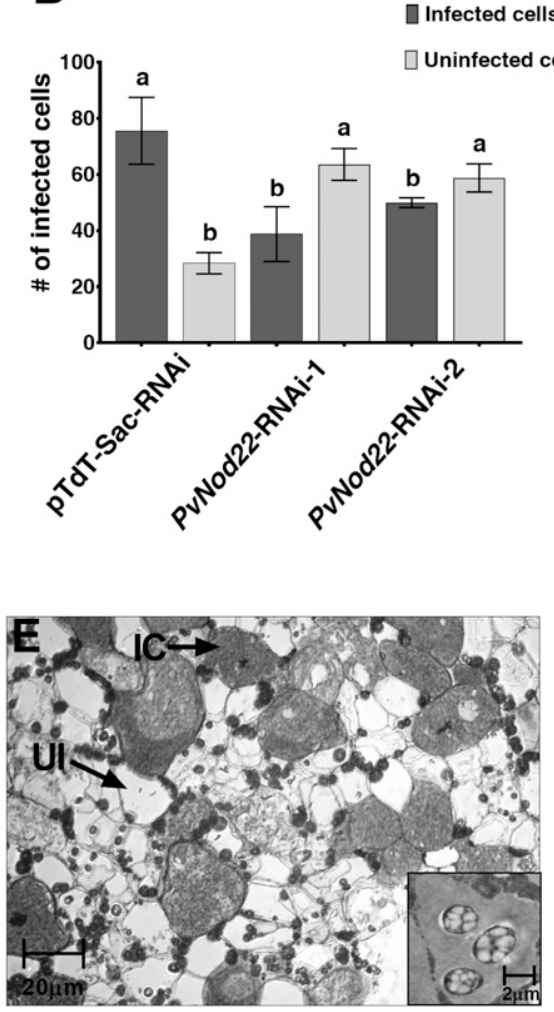

C
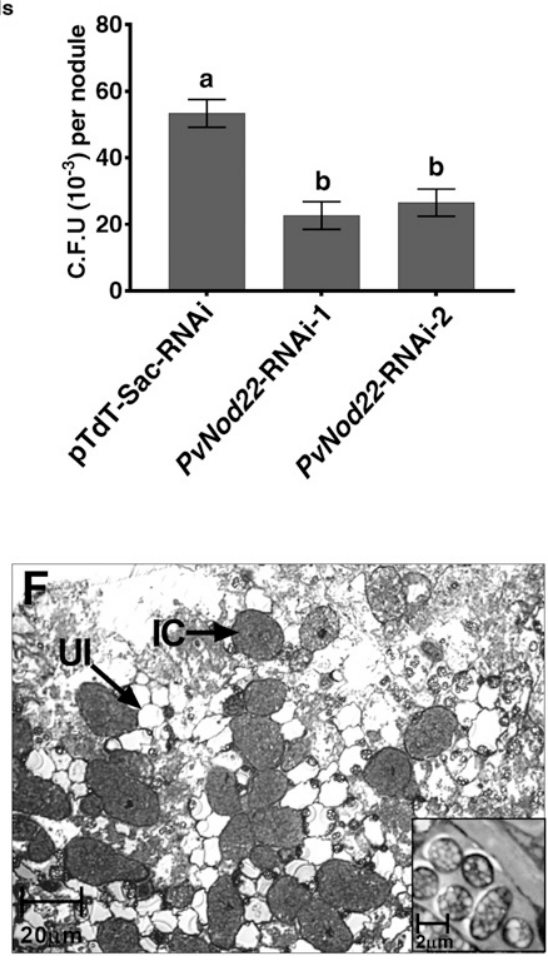

Fig. 4. Low expression levels of PvNod22 result in a higher number of defective root nodules. A, Total number of nodules formed per root (gray columns) and their related nitrogenase activity (black squares in line) of Rhizobium tropici CIAT899 transgenic hairy roots of composite plants transformed with pTdT-Sac-RNA interference (RNAi) (control), PvNod22-RNAi-1, and PvNod22-RNAi-2. Data are means \pm standard deviation (SD) from 20 transgenic roots. Statistical significance was determined using an unpaired two-tailed Student's $t$ test $(P<0.001)$. B, Number of uninfected or infected nodule cells in 100 cells of pTdT-Sac-RNAi (control), PvNod22-RNAi-1, and PvNod22-RNAi-2 nodule sections $(n=3$ ). The statistical significance was determined with an unpaired two-tailed Student's $t$ test, $P<0.001$. C, $R$. tropici CIAT899 survival determined by CFU reisolated from root nodules. Values are means \pm SD from the nodules of nine transgenic roots of composite plants, and statistical significance was determined with an unpaired two-tailed Student's $t$ test. $(P<0.001)$. Optical microscopy of D, pTdT-Sac-RNAi; E, PvNod22-RNAi-1; and F, $P v N o d 22-\mathrm{RNAi}-2$ nodules. Representative images are shown. IC $=$ infected cells and $\mathrm{UI}=$ uninfected cells. Insets in $\mathrm{D}$ to $\mathrm{F}=\mathrm{high}-\mathrm{magnification}$ transmission electron micrographs of bacteroids in these nodules. 
interconnected processes in plants (Liu et al. 2012; Yang et al. 2016), we explored the long-term effect of its downregulation in PvNod22-RNAi nitrogen-fixing nodules by assessing the expression level of UPR and autophagy genes (Fig. 5). In these experiments, 22-dpi nodules of nine transgenic bean roots or nodule-depleted roots were pooled. The expression of some UPR-related genes (Zip17, Zip28, BIP1/2, and PvNod22) is higher in empty-vector transformed nodules (pTdT-SAc-RNAi) than in PvNod22-RNAi nodules (Fig. 5A). It is known that Zip28 and BIP1/2 are part of the UPR associated with normal plant development (Kim et al. 2018; Noh et al. 2003). By contrast, the increased expression of IREa, which encodes an ER-resident kinase/RNase IRE1 that is activated by perturbed ER homeostasis (Chen and Brandizzi 2012), and that of BIP3, which encodes a less well-conserved $\mathrm{BiP}$ paralog expressed only under acute ER stress conditions (Iwata and Koizumi 2012; Liu and Howell 2010; Noh et al. 2003), suggests that, in $P v \operatorname{Nod} 22-\mathrm{RNAi}$ root nodules, the ER stress level is higher. Interestingly, IRE1a has been also implicated in the activation of autophagy (Liu et al. 2012; Yang et al. 2016). Indeed, in $P v N o d 22-R N A i-1$ and PvNod22-RNAi-2 nodules, the expression levels of Beclin1/Atg6, Atg8, VPS15, and PI3K are induced
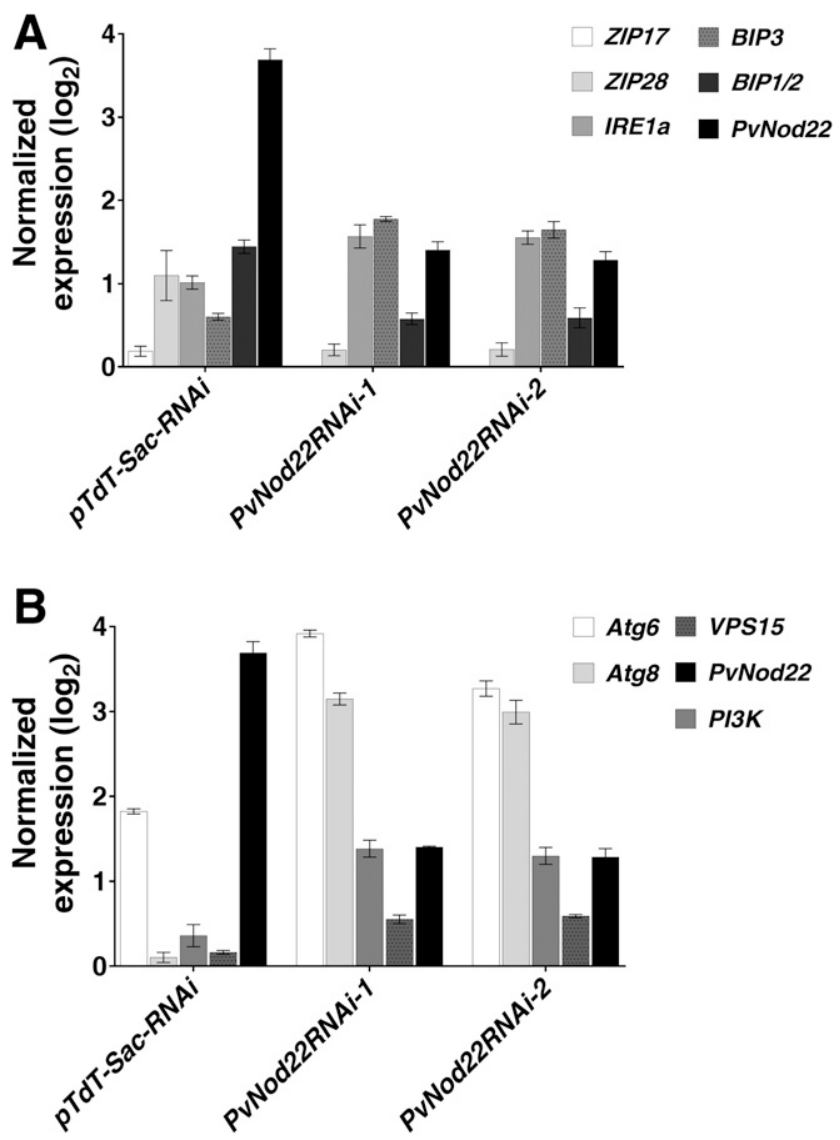

Fig. 5. Silencing of $P v N o d 22$ modifies the expression of unfolded protein response (UPR) and autophagy-related genes in common bean root nodules 22 days postinfection (dpi) elicited by $R$. tropici CIAT899. mRNA levels of A, UPR-related and B, autophagy-related genes in pTdT-Sac-RNA interference (RNAi), PvNod22-RNAi-1, or PvNod22-RNAi-2 nodules 22 dpi. mRNA levels were quantified using reverse-transcription quantitative PCR. Three roots and 12 root nodules were pooled for each biological replicate, and mean values from three biological replicates $(n=3)$ were normalized to the expression of $P v E F 1-\alpha$. Plotted data are the mean $\log _{2}$ values of transcript accumulation \pm standard deviation. The statistical significance was determined using two-way analysis of variance followed by Sidak's multiple comparison test $(*$ indicates $P<0.001)$. compared with the control (Fig. 5B), suggesting that, in the absence of $P v \operatorname{Nod} 22$, autophagy increases to alleviate the ER protein load. Collectively, our data show that $P v \operatorname{Nod} 22$ activity in the ER of nitrogen-fixing nodules makes an important contribution to ER homeostasis.

\section{Silencing of $\mathrm{PvNod} 22$ affects the expression of other ER sHsps.}

Transcript levels of several genes encoding predicted ERresident sHsps of common bean were determined by RT-qPCR. In these experiments, 12 nitrogen-fixing nodules ( $22 \mathrm{dpi}$ ) from control or $P v N o d 22$-silenced root nodules were pooled. Experiments were performed in triplicate with similar results. The Hsp23.7 transcript levels were slightly induced in nodules of the PvNod22-RNAi lines (Fig. 6, $0.8 \pm 0.19$ fold change) compared with the negative control. In contrast, accumulation of Hsp19 transcripts was reduced (Fig. 6, -1.3 \pm 0.09 ) compared with control nodules. The expression levels of other ERsHsps such as Hsp26.4, Hsp57.8, Hsp26.9, Hsp22.3, and Hsp21.4 did not significantly change (Fig. 6). Although $P v N o d 22-R N A i-1$ and PvNod22-RNAi-2 constructs designed in this work are highly specific to $P v N o d 22$ (i.e., do not contain 21-nucleotide complementary segments to any other sHsp sequences, including Hsp19), off-target effects of the RNAi are always a possibility.

\section{DISCUSSION}

$P v$ Nod22 is an sHsp of the ER (Mohammad et al. 2004; Rodriguez-López et al. 2014) preferentially expressed in root nodules of common bean plants (Goodstein et al. 2012). $P v N o d 22$ transcript abundance along nodule ontogeny suggests that it may play a relevant function during this process (Mohammad et al. 2004) (Fig. 1A). In this work, we demonstrated that reduced expression of PvNod22 in transgenic roots of composite bean plants induced by RNAi constructs targeting two independent sequences ( PvNod22-RNAi-1 and PvNod22RNAi-2) affect IT progression (Fig. 3), diminishing nodule bacterial invasion (Fig. 4B to $\mathrm{F}$ ) and thus decreasing overall nitrogen fixation levels (Fig. 4A).

Multiple factors could regulate $P v N o d 22$ expression. In previous work, we showed that PvNod22 expression was not

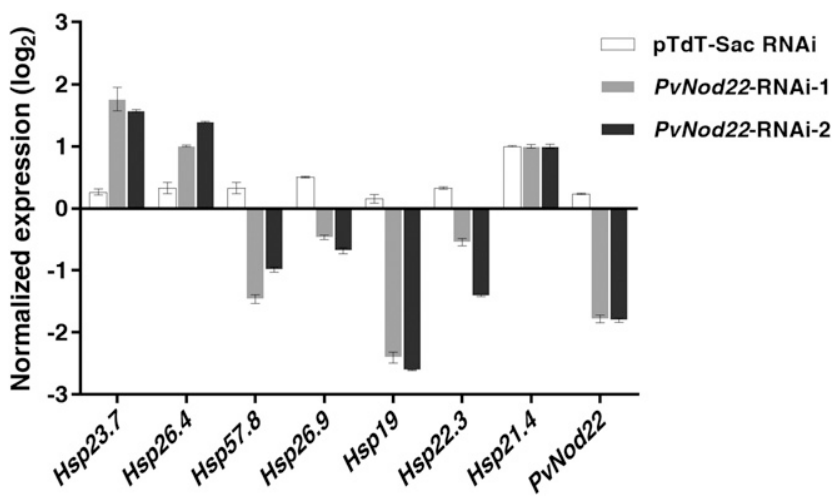

Fig. 6. Downregulation of $P v N o d 22$ in the endoplasmic reticulum (ER) induces minor expression changes in other ER-small heat shock proteins (sHsps). Reverse-transcription quantitative PCR relative expression levels of genes encoding ER-sHsps in root nodules of $P v N o d 22-\mathrm{RNA}$ interference (RNAi)-1 and PvNod22-RNAi-2 roots at 22 days postinfection compared with nodules of transgenic control roots. Data from 12 independent biological replicates were normalized to the expression of $P v E F 1-\alpha$. Plotted data are the mean $\log _{2}$ values of transcript accumulation \pm standard deviation. The statistical significance was determined using two-way analysis of variance followed by Sidak's multiple comparison test $(P<0.001)$. 
induced in common bean plantlets treated with or without tunicamycin (Tm) or dithiothreitol (DTT) (Rodriguez-Lopez et al. 2014). However, in this work, analyzing the expression profile of UPR genes early symbiosis, we observed subtle changes in PvNod22 expression that could be related to the expression of IREa (Fig. 2A). In addition, sequence analysis of the $P v N o d 22$ promoter suggests that $P v \operatorname{Nod} 22$ expression could be controlled by bZip and NAC transcription factors, both implicated in the UPR. Although Tm and DTT in plants are commonly used to induce the UPR in laboratory conditions, both chemicals cause strong stresses in the ER that, in some cases, fail to mimic the UPR caused by unfolded polypeptides (Bergmann et al. 2018). Taking into consideration that the UPR in eukaryotes is a collection of signaling pathways, and that these can have common or different inducers according to stimuli, it is possible that, during symbiosis, the UPR resulting from ER load with unfolded proteins proceed via a well-defined and fine-tuned pathway that involves $P v \operatorname{Nod} 22$.

Interestingly, IREa is required for autophagy (Liu et al. 2012; Yang et al. 2016), which is crucial for symbiosis (EstradaNavarrete et al. 2016; Gavrin et al. 2014; Nanjareddy et al. 2016). These findings suggest that the expression of PvNod22 in nodules of common bean could be mediated by the IRE1a/bZIP60 branch of the UPR pathway (Chen and Brandizzi 2012). In support of this hypothesis, we identified multiple putative binding sites for bZIP and NAC transcription factors in the promoter sequence of $P v N o d 22$. In addition, transcript abundance of the spliced form of bZip60 during nodulation resembles the profile of $P v N o d 22$.

PvNod22 expression during early symbiosis could also be modulated by ROS. Moderate levels of ROS are produced at the initial stages of formation of the legume-rhizobial symbiosis and arbuscular mycorrhizal symbioses (García-Garrido and Ocampo 2002; Moran et al. 2000). Moreover, ROS are required for IT progression (Cárdenas et al. 2008; Montiel et al. 2012). Because $\mathrm{H}_{2} \mathrm{O}_{2}$ treatment induces the expression of $\mathrm{PvNod} 22$ in the aerial organs of bean plants (Rodriguez-López et al. 2014), it is possible that the ROS produced in the root hair after contact with rhizobia and during their progression to nodule cells could modulate $P v N o d 22$ expression. Indeed, recent work demonstrated a strong connection between ER stress and ROS production in plants (Ozgur et al. 2015, 2018).

Finally, considering that PvNod22 silencing results in a dramatic increase in the number of nodules per root (Fig. 4A), it is possible that $P v N o d 22$ expression in early symbiosis could be induced by the hypersensitive response (HR), a resistance mechanism involved in controlling the final number of active nitrogen-fixing nodules per root (Stacey et al. 2006; Vasse et al. 1993). In soybean, the HR suppresses rhizobia infection as early as 0 to 4 dpi (M. Li et al. 2017).

Within the IT, rhizobia enter the root hair cell and eventually ramify into the root cortex. As we showed, IT progression through cortical cells of the nodule primordium is arrested in PvNod22-RNAi transgenic hairy roots of composite bean plants (Fig. 3B and $\mathrm{G}$ compared with 3D), which results in lower nodule infection levels (Fig. 4B, C, E, and F compared with 4D) Although the exact mechanism of IT progression is still under debate, previous studies showed that a localized $\mathrm{Ca}^{2+}$ gradient at the interface of the growing membrane is required to promote the fusion of ER-secretory vesicles (Brewin 2004; Fournier et al. 2008). In this context, it is possible that the ROS produced after contact with rhizobia activates the UPR and $P v N o d 22$ expression to promote the folding of proteins critical for establishing the $\mathrm{Ca}^{2+}$ gradient at the IT membrane such as $\mathrm{Ca}^{2+}$ channels (Brewin 2004). In agreement with this hypothesis, work in Arabidopsis thaliana showed the involvement of heat shock protein 1 in $\mathrm{K}^{+}$ ion channel modulation (Zou et al. 2010). Unfortunately, we were unable to identify $P v \operatorname{Nod} 22$ client proteins in any of our immune or TAP tagging experiments (data not shown).

As observed for UPR-related genes (Fig. 5A), autophagyrelated genes increase their expression level in PvNod22-RNAi transgenic nodules when compared with the control (Fig. 5B). Therefore, it is possible that the lack of $P v \operatorname{Nod} 22$ in active nitrogen-fixing root nodules leads to overloading of the ER's capacity for protein folding. The excessive accumulation of damaged or misfolded proteins could also be aggravated by changes in the abundance of other ER-sHsps (Fig. 6) which, in turn, may intensify the UPR. In this scenario, autophagy may be overinduced to restore ER homeostasis. Collectively, our data and previous data on the ER location and sHsp activity of $P v$ Nod22 (Rodriguez-López et al. 2014) suggest that $P v \operatorname{Nod} 22$ is required for protein homeostasis in the ER during legumerhizobia symbiosis. These changes are likely to occur only in the infected cells of the nodule, where PvNod 22 transcripts have been previously localized (Mohammad et al. 2004).

\section{MATERIALS AND METHODS}

\section{Bacteria and plant materials.}

Escherichia coli DH5 $\alpha$ and Agrobacterium rhizogenes $\mathrm{K} 599$ (Bond and Gresshoff 1993) were grown at 37 and $30^{\circ} \mathrm{C}$, respectively, in Luria-Bertani medium (Gibco BRL) supplemented with the appropriate antibiotics. $R$. tropici CIAT899 (Martínez-Romero et al. 1991), and $R$. tropici-GFP were grown at $30^{\circ} \mathrm{C}$ for 2 days in peptone-yeast extract (PY) medium, as previously described (Martínez-Romero et al. 1991).

Bean ( $P$. vulgaris L. 'Negro Jamapa') seed were surface sterilized and germinated in the dark for 2 days. The 2-day-old seedlings were transferred to pots containing sterilized vermiculite, inoculated with $1 \mathrm{ml}$ of $R$. tropici CIAT899 diluted to an optical density at $600 \mathrm{~nm}$ of 0.05 (equivalent to $7 \times 10^{7}$ ) in $10 \mathrm{mM} \mathrm{MgSO}_{4}$, and grown in a glasshouse with a controlled environment ( $16 \mathrm{~h}$ of light and $8 \mathrm{~h}$ of darkness at 26 to $28^{\circ} \mathrm{C}$ ). Plants were irrigated with BD medium (Broughton and Dilworth 1971) without nitrate. Control plants (not inoculated with rhizobia) were irrigated with BD medium supplemented with $8 \mathrm{mM} \mathrm{KNO}_{3}$ and grown in the same conditions. Alternatively, bean composite plants with transgenic roots were generated as described (Estrada-Navarrete et al. 2007) and $R$. tropici was inoculated as described. Wild-type or transgenic roots and nodules were harvested at different postinoculation times (hours and days postinoculation) and stored at $-80^{\circ} \mathrm{C}$ until use or, alternatively, fixed and processed as described.

\section{Plasmid construction.}

To develop the PvNod22-RNAi-1 and PvNod22-RNAi-2 constructs, 303 bp upstream of the PvNod22 start codon or $303 \mathrm{bp}$ downstream of the stop codon, respectively, were PCR amplified with specific primers. We used $P$. vulgaris 'Negro Jamapa' genomic DNA as the template. PCR products were independently cloned into the $\mathrm{pENTR/D-TOPO}$ vector (Invitrogen) using the Gateway system, confirmed by sequencing, and recombined into the destination binary pTDT-RNAi vector (Karimi et al. 2007; Valdés-López et al. 2008), which includes the 'Tomato' fluorescent protein (tdTomato protein) as a reporter. All clones were confirmed by nucleotide sequencing. The pTdT-RNAi vector containing an unrelated nucleotidescrambled sequence (pTdT-Sac_RNAi) was used as the negative control in all experiments. pTdT-Sac_RNAi-transformed hairy roots were indistinguishable from untransformed hairy roots. Transgenic hairy roots were selected using an epifluorescence stereomicroscope based on the fluorescence of red fluorescent protein (RFP). RFP fluorescence was excited at $561 \mathrm{~nm}$ using a solid-state laser, and the emission was filtered 
using a 640/50-nm band-pass filter. Transgenic roots overexpressing PvNod22 were confirmed by RT-qPCR.

\section{RNA isolation and transcript accumulation analyses using RT-qPCR.}

Total RNA was isolated from roots and root nodules using the ZR Plant RNA Miniprep kit (Zymo Research), following the manufacturer's instructions. RNA quantity was determined spectrophotometrically (Nanodrop 2000c; Thermo Fisher Scientific) and RNA quality was determined via electrophoresis. For reverse transcription, $3 \mu \mathrm{g}$ of total RNA was treated with DNaseI (RNase-free; Invitrogen), and $1.5 \mu \mathrm{g}$ of total RNA was reverse transcribed using the Revert Aid H Minus First-strand cDNA synthesis Kit for RT-qPCR (Thermo Fisher Scientific) according to the manufacturer's instructions. For qPCR, $15 \mu \mathrm{l}$ qPCR amplifications using Maxima SYBR Green qPCR Master Mix (Fermentas) were performed on an iCycle iQ5 apparatus (version 2.1; Bio-Rad). A control sample without reverse transcription was included to confirm the absence of contaminating DNA. The relative numbers for cycle threshold of each gene were normalized to the housekeeping gene $P v E F 1-\alpha$ (Nicot et al. 2005), which has been tested in our laboratory and is a stable reference gene for nodulation studies in common bean (data not shown). Data were analyzed using the iQ5 Optical System Software (version 2.1; Bio-Rad). Five or more individual roots or nodules were pooled for each biological replicate. The presented data are averages of two or three biological replicates, and each biological replicate was assessed in triplicate.

\section{Acetylene reduction assay.}

The nitrogenase activity of untransformed or transgenic nodules was determined by measuring the reduction of acetylene (Vessey 1994). Nodulated roots of common bean plants were placed in glass vials closed with serum caps. Air was immediately withdrawn from the closed vial and replaced with acetylene to a final concentration of $10 \%$ of the gas phase. Samples were incubated for $40 \mathrm{~min}$ at room temperature, and the averages of the constant maximum rates were recorded via gas chromatography in a Variant model 3300 chromatograph (Agilent Technologies), as described (Ramírez et al. 1999). Specific activity is expressed as micromoles of ethylene per hour per gram of nodule dry weight. The nitrogen-fixation capacity of wild-type or untransformed A. rhizogenes K599 root nodules was considered to be $100 \%$.

\section{Quantitative evaluation of root nodule bacteria.}

Common bean plants were grown and inoculated with $R$. tropici as described above. Nine root nodules were harvested from each plant at $22 \mathrm{dpi}$, surface sterilized by immersion in ethanol $(95 \%, \mathrm{vol} / \mathrm{vol})$ for $10 \mathrm{~s}$ and then in sodium hypochlorite $(10 \%, \mathrm{vol} / \mathrm{vol})$ for $10 \mathrm{~min}$, rinsed with sterile water five times, and homogenized in $1.5 \mathrm{ml}$ of PY medium containing nalidixic acid at $20 \mu \mathrm{g} \mathrm{ml}^{-1}$ and tetracycline at $10 \mu \mathrm{g} \mathrm{ml}^{-1}$. Bacterial cultures were serially diluted and plated on PY medium plates with the appropriate antibiotics. Plates were incubated at $30^{\circ} \mathrm{C}$ for 3 days and CFU were counted. As the negative control, $200 \mu \mathrm{l}$ of the wash water used in the final rinse was plated in the same growth medium.

\section{Antibodies and immunoblotting.}

Root and root nodule protein samples were prepared according to Lledías et al. (2017). Equal amounts of protein ( $\geq 20 \mathrm{~g}$ of total protein) were loaded into each lane and resolved by $15 \%$ sodium dodecyl sulfate polyacrylamide gel electrophoresis (Laemmli 1970) loaded with $10 \mu \mathrm{g}$ of protein per lane. The gel was electroblotted onto Immobilon-P polyvinyl diflouride membranes (Millipore Corp.). Blotted membranes were washed in TBS (30 mM Tris [pH 8.0] and $150 \mathrm{mM} \mathrm{NaCl})$ for 10 min and blocked in 5\% skim milk in TTBS (TBS with $0.1 \%$ Triton $\mathrm{X}-100$ ) for $1 \mathrm{~h}$ at room temperature. The membrane was incubated with the anti $P v \operatorname{Nod} 22$ polyclonal antibody (custom-made in rabbits against the VFSCVLELPFRSDADVVVE $P v$ Nod22 peptide; GenScript) in TTBS and incubated overnight at $4^{\circ} \mathrm{C}$. The membrane was washed three times with TTBS and incubated with peroxidase-conjugated immunoglobulin $\mathrm{G}$ antirabbit in TTBS (Sigma-Aldrich) for $1 \mathrm{~h}$ at room temperature. Signal detection was achieved using SuperSignal West Pico PLUS Substrate (Thermo Fisher Scientific).

\section{Microscopy of roots and root nodules.}

Transgenic hairy roots expressing the PvNod22-RNAi-1 and $P v N o d 22-\mathrm{RNAi}-2$ vectors were selected using an epifluorescence stereomicroscope based on the fluorescence of RFP. RFP fluorescence was excited at $561 \mathrm{~nm}$ using a solid-state laser, and the emission was filtered using a 640/50-nm bandpass filter. Roots and root nodules were mounted on microscope slides in $0.1 \mathrm{M}$ phosphate buffer, $\mathrm{pH}$ 7.4. All fluorescence images were taken using a confocal microscope (LSM510; Carl Zeiss). Z-projected confocal images were generated using Fluoview Viewer (Olympus Corporation) and ZEN Black (Carl Zeiss).

For optical microscopy, control or transgenic root nodules were fixed in $2.5 \%$ glutaraldehyde and $4 \%$ paraformaldehyde in $0.1 \mathrm{M} \mathrm{Na}$-cacodylate buffer, $\mathrm{pH} 7.2$, at $4^{\circ} \mathrm{C}$ for $16 \mathrm{~h}$; postfixed with $1 \%$ osmium tetroxide for $2 \mathrm{~h}$ at $4{ }^{\circ} \mathrm{C}$; and dehydrated through an ethanol gradient (from 10 to $100 \%$ ). Samples were then embedded in LR-White resin (London Resin Company, Ltd.) and polymerized under ultraviolet light at $-20^{\circ} \mathrm{C}$ for $48 \mathrm{~h}$. Semithin sections $(0.5$ to $1.0 \mathrm{~mm})$ were produced using an ultramicrotome (Ultracut R; Leica) and stained with $0.1 \%$ toluidine blue. For transmission electron microscopy, samples were stained with uranyl acetate. Thin $(60-\mathrm{nm})$ sections were prepared with an ultramicrotome (Ultracut R). The electron microscopy analyses were performed using an EM900 transmission electron microscope (Carl Zeiss) dual-vision coupledcamera system (Gatan, Inc.).

\section{Statistical analyses.}

In all experiments, at least three biological samples were analyzed and three technical repeats were performed for each biological sample. Graph Pad Prism Version 6.0 for Windows 10 (GraphPad Software Inc.) was used to calculate standard deviation between experimental samples. Statistical significance was calculated by one-way analysis of variance (ANOVA) for multiple comparisons to identify significant changes in gene expression among the various plant conditions. The change in gene expression was the dependent variable. A $P$ value $\leq 0.05$ was considered to be significant. ANOVA was followed by Tukey's test.

\section{ACKNOWLEDGMENTS}

We thank A. Leija, X. Alvarado-Affantranger, O. Santana, and G. Zavala for their technical advice; the Laboratorio Nacional de Microscopía Avanzada at the Instituto de Biotecnología of the Universidad Nacional Autónoma de México for the use of their equipment; P. Gaytán, J. Yañez, and E. López for primer synthesis and DNA sequencing (Unidad de Síntesis y Secuenciación de ADN at the Instituto de Biotecnología); and the team of Plant Editors for their detailed and professional editing of this manuscript.

\section{AUTHOR-RECOMMENDED INTERNET RESOURCES}

Plant Editors: https://planteditors.com/ GenScript: http://www.genscript.com/ 


\section{LITERATURE CITED}

Angelos, E., Ruberti, C., Kim, S. J., and Brandizzi, F. 2017. Maintaining the factory: The roles of the unfolded protein response in cellular homeostasis in plants. Plant J. 90:671-682.

Bailey, D., and O'Hare, P. 2007. Transmembrane bZIP transcription factors in ER stress signaling and the unfolded protein response. Antioxid. Redox Signal. 9:2305-2322.

Bao, Y., and Howell, S. H. 2017. The unfolded protein response supports plant development and defense as well as responses to abiotic stress. Front. Plant Sci. 8:344.

Bergmann, T. J., Fregno, I., Fumagalli, F., Rinaldi, A., Bertoni, F., Boersema, P. J., Picotti, P., and Molinari, M. 2018. Chemical stresses fail to mimic the unfolded protein response resulting from luminal load with unfolded polypeptides. J. Biol. Chem. 293:5600-5612.

Bond, J. E., and Gresshoff, P. M. 1993. Soybean transformation to study molecular physiology. Pages 25-44 in: Plant Responses to the Environment. CRC Press, London, U.K.

Brewin, N. J. 2004. Plant Cell Wall remodelling in the rhizobium-legume symbiosis. Crit. Rev. Plant Sci. 23:293-316.

Broughton, W. J., and Dilworth, M. J. 1971. Control of leghaemoglobin synthesis in snake beans. Biochem. J. 125:1075-1080.

Cárdenas, L., Martínez, A., Sánchez, F., and Quinto, C. 2008. Fast, transient and specific intracellular ROS changes in living root hair cells responding to Nod factors (NFs). Plant J. 56:802-813.

Cermola, M., Fedorova, E., Taté, R., Riccio, A., Favre, R., and Patriarca, E. J. 2000. Nodule invasion and symbiosome differentiation during Rhizobium etli-Phaseolus vulgaris symbiosis. Mol. Plant-Microbe Interact. 13:733-741.

Chen, Y., and Brandizzi, F. 2012. AtIRE1A/AtIRE1B and AGB1 independently control two essential unfolded protein response pathways in Arabidopsis. Plant J. 69:266-277.

Chi, Y. H., Melencion, S. M. B., Alinapon, C. V., Kim, M. J., Lee, E. S., Paeng, S. K., Park, J. H., Nawkar, G. M., Jung, Y. J., Chae, H. B., Kang, C. H., and Lee, S. Y. 2017. The membrane-tethered NAC transcription factor, AtNTL7, contributes to ER-stress resistance in Arabidopsis. Biochem. Biophys. Res. Commun. 488:641-647.

Chow, C. N., Zheng, H. Q., Wu, N. Y., Chien, C. H., Huang, H. D., Lee, T. Y., Chiang-Hsieh, Y. F., Hou, P. F., Yang, T. Y., and Chang, W. C. 2016. PlantPAN 2.0: An update of plant promoter analysis navigator for reconstructing transcriptional regulatory networks in plants. Nucleic Acids Res. 44:D1154-D1160.

Crespi, M., and Frugier, F. 2008. De novo organ formation from differentiated cells: Root nodule organogenesis. Sci. Signal. 1:re11.

Deng, Y., Humbert, S., Liu, J. X., Srivastava, R., Rothstein, S. J., and Howell, S. H. 2011. Heat induces the splicing by IRE1 of a mRNA encoding a transcription factor involved in the unfolded protein response in Arabidopsis. Proc. Natl. Acad. Sci. U.S.A. 108:72477252.

Estrada-Navarrete, G., Alvarado-Affantranger, X., Olivares, J. E., Guillén, G., Díaz-Camino, C., Campos, F., Quinto, C., Gresshoff, P. M., and Sánchez, F. 2007. Fast, efficient and reproducible genetic transformation of Phaseolus spp. by Agrobacterium rhizogenes. Nat. Protoc. 2: 1819-1824.

Estrada-Navarrete, G., Cruz-Mireles, N., Lascano, R., Alvarado-Affantranger, X., Hernández-Barrera, A., Barraza, A., Olivares, J. E., Arthikala, M. K., Cárdenas, L., Quinto, C., and Sanchez, F. 2016. An autophagy-related kinase is essential for the symbiotic relationship between Phaseolus vulgaris and both rhizobia and arbuscular mycorrhizal fungi. Plant Cell 28:2326-2341.

Evans, P. J., Gallesi, D., Mathieu, C., Hernández, M. J., De Felipe, M., Halliwell, B., and Puppo, A. 1999. Oxidative stress occurs during soybean nodule senescence. Planta 208:73-79.

Fournier, J., Timmers, A. C. J., Sieberer, B. J., Jauneau, A., Chabaud, M., and Barker, D. G. 2008. Mechanism of infection thread elongation in root hairs of Medicago truncatula and dynamic interplay with associated rhizobial colonization. Plant Physiol. 148:1985-1995.

García-Garrido, J. M., and Ocampo, J. A. 2002. Regulation of the plant defence response in arbuscular mycorrhizal symbiosis. J. Exp. Bot. 53: $1377-1386$

Gavrin, A., Kaiser, B. N., Geiger, D., Tyerman, S. D., Wen, Z., Bisseling, T., and Fedorova, E. E. 2014. Adjustment of host cells for accommodation of symbiotic bacteria: Vacuole defunctionalization, HOPS suppression, and TIP1g retargeting in Medicago. Plant Cell 26:3809-3822.

Goodstein, D. M., Shu, S., Howson, R., Neupane, R., Hayes, R. D., Fazo, J., Mitros, T., Dirks, W., Hellsten, U., Putnam, N., and Rokhsar, D. S. 2012. Phytozome: A comparative platform for green plant genomics. Nucleic Acids Res. 40:D1178-D1186.
Hampel, M., Jakobi, M., Schmitz, L., Meyer, U., Finkernagel, F., Doehlemann, G., and Heimel, K. 2016. Unfolded Protein Response (UPR) Regulator Cib1 Controls Expression of Genes Encoding Secreted Virulence Factors in Ustilago maydis. PLoS One 11:e0153861.

Hof, A., Zechmann, B., Schwammbach, D., Hückelhoven, R., and Doehlemann, G. 2014. Alternative cell death mechanisms determine epidermal resistance in incompatible barley-Ustilago interactions. Mol. Plant-Microbe Interact. 27:403-414.

Iwata, Y., and Koizumi, N. 2012. Plant transducers of the endoplasmic reticulum unfolded protein response. Trends Plant Sci. 17:720-727.

Kabbage, M., Williams, B., and Dickman, M. B. 2013. Cell death control: The interplay of apoptosis and autophagy in the pathogenicity of Sclerotinia sclerotiorum. PLoS Pathog. 9:e1003287.

Karimi, M., Depicker, A., and Hilson, P. 2007. Recombinational cloning with plant gateway vectors. Plant Physiol. 145:1144-1154.

Kim, J.-S., Yamaguchi-Shinozaki, K., and Shinozaki, K. 2018. ERAnchored transcription factors bZIP17 and bZIP28 regulate root elongation. Plant Physiol. 176:2221-2230.

Laemmli, U. K. 1970. Cleavage of structural proteins during the assembly of the head of bacteriophage T4. Nature 227:680-685.

Li, M., Yasuda, M., Yamaya-Ito, H., Maeda, M., Sasaki, N., Nagata, M., Suzuki, A., Okazaki, S., Sekimoto, H., Yamada, T., Ohkama-Ohtsu, N., and Yokoama, T. 2017. Involvement of programmed cell death in suppression of the number of root nodules formed in soybean induced by Bradyrhizobium infection. Soil Sci. Plant Nutr. 63:561-577.

Li, Q., Wei, H., Liu, L., Yang, X., Zhang, X., and Xie, Q. 2017. Unfolded protein response activation compensates endoplasmic reticulumassociated degradation deficiency in Arabidopsis. J. Integr. Plant Biol. 59:506-521.

Liu, J. X., and Howell, S. H. 2010. bZIP28 and NF-Y transcription factors are activated by ER stress and assemble into a transcriptional complex to regulate stress response genes in Arabidopsis. Plant Cell 22:782-796.

Liu, Y., Burgos, J. S., Deng, Y., Srivastava, R., Howell, S. H., and Bassham, D. C. 2012. Degradation of the endoplasmic reticulum by autophagy during endoplasmic reticulum stress in Arabidopsis. Plant Cell 24: 4635-4651.

Lledías, F., Hernández, F., Rivas, V., García-Mendoza, A., Cassab, G. I., and Nieto-Sotelo, J. 2017. A rapid and reliable method for total protein extraction from succulent plants for proteomic analysis. Protein J. 36: 308-321.

Ma, W., and Berkowitz, G. A. 2007. The grateful dead: Calcium and cell death in plant innate immunity. Cell. Microbiol. 9:2571-2585.

Martínez-Romero, E., Segovia, L., Mercante, F. M., Franco, A. A., Graham, P., and Pardo, M. A. 1991. Rhizobium tropici, a novel species nodulating Phaseolus vulgaris L. beans and Leucaena sp. trees. Int. J. Syst. Bacteriol. 41:417-426.

Martinon, F., and Glimcher, L. H. 2011. Regulation of innate immunity by signaling pathways emerging from the endoplasmic reticulum. Curr. Opin. Immunol. 23:35-40.

Matamoros, M. A., Baird, L. M., Escuredo, P. R., Dalton, D. A., Minchin, F. R., Iturbe-Ormaetxe, I., Rubio, M. C., Morán, J. F., Gordon, A. J., and Becana, M. 1999. Stress-induced legume root nodule senescence. Physiological, biochemical, and structural alterations. Plant Physiol. 121:97-112.

Matamoros, M. A., Dalton, D. A., Ramos, J., Clemente, M. R., Rubio, M. C., and Becana, M. 2003. Biochemistry and molecular biology of antioxidants in the rhizobia-legume symbiosis. Plant Physiol. 133: 499-509.

Mishiba, K., Nagashima, Y., Suzuki, E., Hayashi, N., Ogata, Y., Shimada, Y., and Koizumi, N. 2013. Defects in IRE1 enhance cell death and fail to degrade mRNAs encoding secretory pathway proteins in the Arabidopsis unfolded protein response. Proc. Natl. Acad. Sci. U.S.A. 110:5713-5718.

Mohammad, A., Miranda-Ríos, J., Navarrete, G. E., Quinto, C., Olivares, J. E., García-Ponce, B., and Sánchez, F. 2004. Nodulin 22 from Phaseolus vulgaris protects Escherichia coli cells from oxidative stress. Planta 219:993-1002.

Montiel, J., Nava, N., Cárdenas, L., Sánchez-López, R., Arthikala, M. K., Santana, O., Sánchez, F., and Quinto, C. 2012. A Phaseolus vulgaris NADPH oxidase gene is required for root infection by Rhizobia. Plant Cell Physiol. 53:1751-1767.

Moran, J. F., Iturbe-Ormaetxe, I., Matamoros, M. A., Rubio, M. C., Clemente, M. R., Brewin, N. J., and Becana, M. 2000. Glutathione and homoglutathione synthetases of legume nodules. Cloning, expression, and subcellular localization. Plant Physiol. 124:1381-1392.

Moreno, A. A., Mukhtar, M. S., Blanco, F., Boatwright, J. L., Moreno, I., Jordan, M. R., Chen, Y., Brandizzi, F., Dong, X., Orellana, A., and 
Pajerowska-Mukhtar, K. M. 2012. IRE1/bZIP60-mediated unfolded protein response plays distinct roles in plant immunity and abiotic stress responses. PLoS One 7:e31944.

Mortier, V., Holsters, M., and Goormachtig, S. 2012. Never too many? How legumes control nodule numbers. Plant Cell Environ. 35:245-258.

Nagashima, Y., Iwata, Y., Ashida, M., Mishiba, K., and Koizumi, N. 2014. Exogenous salicylic acid activates two signaling arms of the unfolded protein response in Arabidopsis. Plant Cell Physiol. 55:1772-1778.

Nagashima, Y., Mishiba, K., Suzuki, E., Shimada, Y., Iwata, Y., and Koizumi, N. 2011. Arabidopsis IRE1 catalyses unconventional splicing of bZIP60 mRNA to produce the active transcription factor. Sci. Rep. 1: Article 29.

Nanjareddy, K., Blanco, L., Arthikala, M.-K., Alvarado-Affantranger, X., Quinto, C., Sánchez, F., and Lara, M. 2016. A legume TOR protein kinase regulates rhizobium symbiosis and is essential for infection and nodule development. Plant Physiol. 172:2002-2020.

Nicot, N., Hausman, J. F., Hoffmann, L., and Evers, D. 2005. Housekeeping gene selection for real-time RT-PCR normalization in potato during biotic and abiotic stress. J. Exp. Bot. 56:2907-2914.

Noh, S.-J., Kwon, C.-S., Oh, D.-H., Moon, J. S., and Chung, W. I. 2003. Expression of an evolutionarily distinct novel BiP gene during the unfolded protein response in Arabidopsis thaliana. Gene 311:81-91.

Ozgur, R., Uzilday, B., Iwata, Y., Koizumi, N., and Turkan, I. 2018. Interplay between the unfolded protein response and reactive oxygen species: A dynamic duo. J. Exp. Bot. 69:3333-3345.

Ozgur, R., Uzilday, B., Sekmen, A. H., and Turkan, I. 2015. The effects of induced production of reactive oxygen species in organelles on endoplasmic reticulum stress and on the unfolded protein response in Arabidopsis. Ann. Bot. 116:541-553.

Ramírez, M., Valderrama, B., Arredondo-Peter, R., Soberón, M., Mora, J., and Hernández, G. 1999. Rhizobium etli genetically engineered for the heterologous expression of Vitreoscilla sp. hemoglobin: Effects on freeliving and symbiosis. Mol. Plant-Microbe Interact. 12:1008-1015.

Rodriguez-López, J., Martínez-Centeno, C., Padmanaban, A., Guillén, G., Olivares, J. E., Stefano, G., Lledías, F., Ramos, F., Ghabrial, S. A., Brandizzi, F., Rocha-Sosa, M., Díaz-Camino, C., and Sanchez, F. 2014. Nodulin 22, a novel small heat-shock protein of the endoplasmic reticulum, is linked to the unfolded protein response in common bean. Mol. Plant-Microbe Interact. 27:18-29.
Shao, H., Wang, H., and Tang, X. 2015. NAC transcription factors in plant multiple abiotic stress responses: Progress and prospects. Front. Plant Sci. 6:902.

Stacey, G., McAlvin, C. B., Kim, S. Y., Olivares, J., and Soto, M. J. 2006. Effects of endogenous salicylic acid on nodulation in the model legumes Lotus japonicus and Medicago truncatula. Plant Physiol. 141: 1473-1481.

Stael, S., Wurzinger, B., Mair, A., Mehlmer, N., Vothknecht, U. C., and Teige, M. 2012. Plant organellar calcium signalling: An emerging field. J. Exp. Bot. 63:1525-1542.

Stougaard, J. 2001. Genetics and genomics of root symbiosis. Curr. Opin. Plant Biol. 4:328-335.

Sun, L., Yang, Z. T., Song, Z. T., Wang, M. J., Sun, L., Lu, S. J., and Liu, J. X. 2013. The plant-specific transcription factor gene NAC103 is induced by bZIP60 through a new cis-regulatory element to modulate the unfolded protein response in Arabidopsis. Plant J. 76:274-286.

Valdés-López, O., Arenas-Huertero, C., Ramírez, M., Girard, L., Sánchez, F., Vance, C. P., Luis Reyes, J., and Hernández, G. 2008. Essential role of MYB transcription factor: PvPHR1 and microRNA: PvmiR399 in phosphorus-deficiency signalling in common bean roots. Plant Cell Environ. 31:1834-1843.

Vasse, J., de Billy, F., and Truchet, G. 1993. Abortion of infection during the Rhizobium meliloti-alfalfa symbiotic interaction is accompanied by a hypersensitive reaction. Plant J. 4:555-566.

Vessey, J. K. 1994. Measurement of nitrogenase activity in legume root nodules: In defence of the acetylene reduction assay. Plant Soil 158: 151-162.

Yang, X., Srivastava, R., Howell, S. H., and Bassham, D. C. 2016. Activation of autophagy by unfolded proteins during endoplasmic reticulum stress. Plant J. 85:83-95.

Yang, Z. T., Wang, M. J., Sun, L., Lu, S. J., Bi, D. L., Sun, L., Song, Z. T. Zhang, S. S., Zhou, S. F., and Liu, J. X. 2014. The membrane-associated transcription factor NAC089 controls ER-stress-induced programmed cell death in plants. PLoS Genet. 10:e1004243.

Zou, J. J., Wei, F. J., Wang, C., Wu, J. J., Ratnasekera, D., Liu, W. X., and Wu, W. H. 2010. Arabidopsis calcium-dependent protein kinase CPK10 functions in abscisic acid- and $\mathrm{Ca} 2+-$ mediated stomatal regulation in response to drought stress. Plant Physiol. 154:1232-1243. 